\title{
色素性乾皮症の分子機構と異質性
}

\author{
武 部啓 \\ (京都大学放射線生物研究センター)

\section{Molecular Mechanisms of DNA Repair Defects and Heterogeneity in Xeroderma Pigmentosum} \\ Hiraku TAKEBE \\ Radiation Biology Center, Kyoto University
}

\begin{abstract}
Summary Xeroderma pigmentosum (XP) is an autosomal recessive hereditary disease, first described about 100 years ago. Ultraviolet light in solar spectrum has been believed to cause the skin lesions which often develop into skin cancers. Cleaver's discovery (1968) that the defect in repair of UV damage in DNA is responsible for the disease suggested that there is common DNA repair mechanisms between human being and microorganisms in which the molecular mechanisms of the repair defects have been extensively investigated. This prediction has turned out to be generally true by using the techniques similar to those applied in microorganisms.

Fifty XP patients in Japan were examined for their clinical characteristics and the DNA repair of their cells. Results are summarized as follows. (1) More than a half of the patients were children under 13 years of age. (2) Genetic complementation tests were performed on 23 cell strains from the patients; 21 belonging to group $A, 1$ to $D$ and 1 to E. There was no group $C$ patient which is the most frequent in Europe and U.S.A. (3) Host-cell reactivation of UV-irradiated herpes simplex virus has been shown to be the most reliable method for decisive diagnosis of the XP, reflecting the relative capacities of excision repair.

The high frequency of XP patients with low DNA repair capacities, including group A patients, may account for the apparent high frequency of XP patients in Japan. Age distribution of the cancer bearing patients and their DNA repair characteristics suggest that almost all XP patients except for those with nearly normal level of excision repair have developed or will develop skin cancers.
\end{abstract}

色素性乾皮淀（xeroderma pigmentosum，以下 XP と略記する）快常染色体性劣性遺 伝子による皮膚疾患で，太陽光にさらされた皮膚が色素沈着と乾皮症状を呈し，大多数の 患者が皮膚がんを生ずるに至る，その原因注太陽光中の紫外線 (UV) Kよるものと考え られていたが，1968年 Cleaver ${ }^{11}$ は XP 患者の細胞が DNA に生じた UV 損傷を修復 できないことを発見してそれを実証した．DNA 修復の研究はそれるで主に大腸菌を用い 
て微生物で研究が進めら礼，その成果はめざましく，分子生物学的研究により機構も詳細

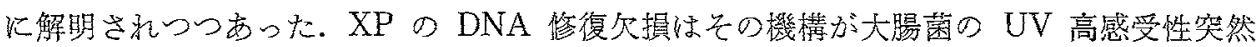

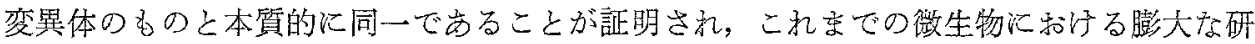
究成果名ヒトの医学的問題, 特に発が九機構の研究に役立つ可能性が示されたといるる。

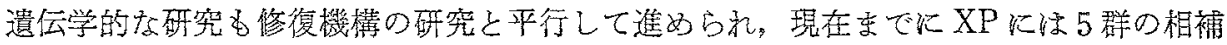
性群と variant とよばれるものの計 6 型方存在するとされている. 日本のXP患者和上 びその細胞の DNA 修復については，筆者らが約50例について多角的な検討空行った。 そ

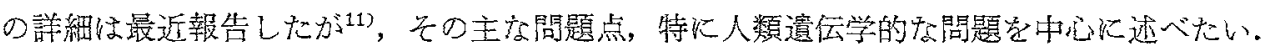

\section{DNA 修復とその欠陥}

1958年, 大腸菌で極端に UV に高感受性の突然変異株が分離され， $B_{\mathbb{S}}\left(\right.$ 後に $B_{S-1}$ ）を 名付けられた。なぜ普通の株々り数十倍も高感受性（殺菌灯によって同じ割合に殺すのに 普通の株の数十分の 1 UV 線量しかいらない）を示すのか，従来の考え方では説明で

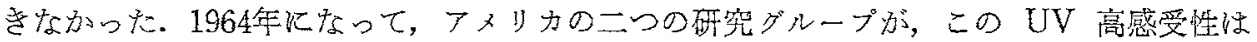
DNA に生じた UV 損傷（ピリミジンダイマー）を修復できないことによって生ずること を証明した。すなわち，普通の大腸菌（野生株）はDNA に生じ損傷の大部分学修復す

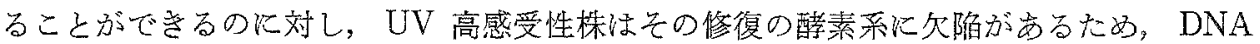
に生じた UV 損傷がそのま残り，致死効果となるのである。

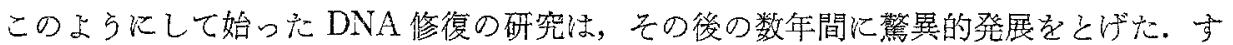
度わち大腸菌の染色体上汇修復遺伝子がいくつか決定され，乞の修復機構は大晹菌自身の DNA だけでなく、ファージのDNA のUV 損傷も修復できること，最初発見さ机た 除去修復 (excision repair) だけでなく,組換克に関係した修復 (recombinational repair)

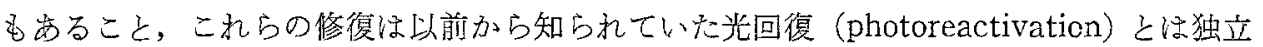
で要るが，作用する基質は同一で岗ること，UV 以外のX線や化学物質によって生じた DNA 韻傷もこれらの修復系の一部尤って修復されることなど，放射線生物学の教科書 が，2，3年で全面的炕書きかえら机标ならないはどの急速な進歩であった。しかし，こ



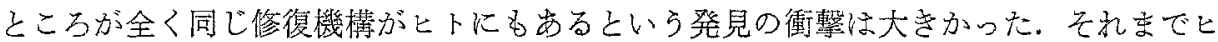
トの細胞を含光培養細胞でるDNA 修復の存在快確認さ礼ていたが，大腸菌のよらなUV

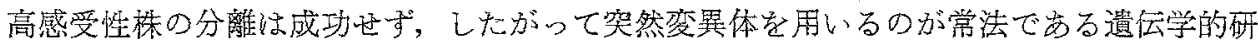
究は全く着手されていなかった。矢れが遺伝病婁者という形で実在したことは，人類遺伝 学的見地がらすれ礼当然のことではかっても，大腸菌での著しいUV 高感受性，すなわ

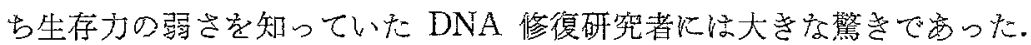

\section{2. 色素性乾皮症における DNA 修復欠損}

XP の研究にはいくつかの難関があった。焉ず研究枍料としての細胞を，患者から直接 採取培養せ放代ならない点が，これまで系統化した Hela 細胞と加L細胞とが親しんで きた細胞生物学者にとって容易なことではなかった，次にDNA 修復の研究が隍とえどす べて大腸菌などの徽生物でなされてきなことも，細胞生物学者にとって着手しにくい点で 


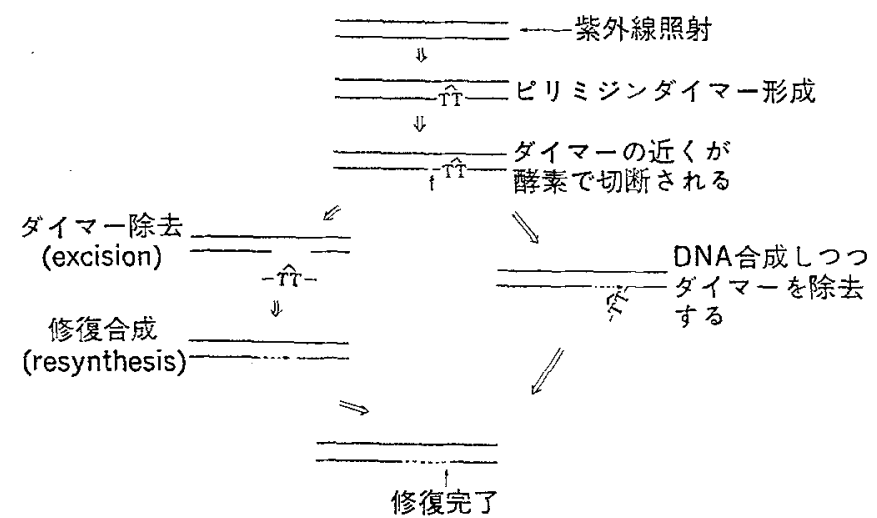

图 1. 除去修復のモデル

cut and patch (左) と patch and cut (右) が考党られるが， 後者を支持するデータが多い。

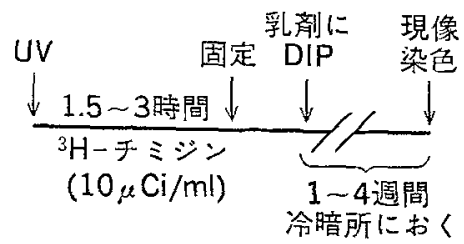

图 2. UV 照射後の不定期 DNA 合成を湘定导る方法

あった。扔そらくこのよらな理由から，XP 研究の重要性は認識されつつ子実際の研究の ペースは決して速くはなかった。

XP の DNA 修復欠損は，大腸菌て除去修復 (excision repair) として発見されたもの

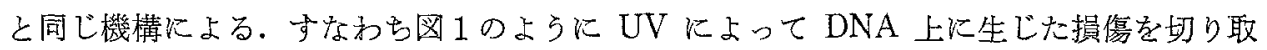
って，あとを穴埋めするようにして修復される，XP ではとの過程の最初の段階，すなる ら UV 特異的なエンドヌクレアーぜが欠損しているか，活性が低下しているものと考光

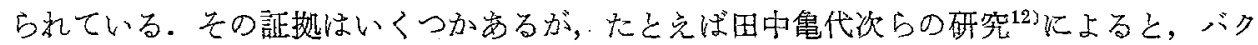
テリオファージ T4 で知られて精製されている UV 損傷特異的なエンドヌクレアーゼV

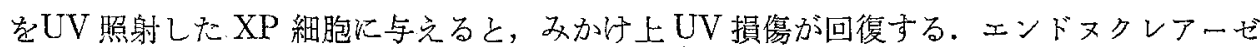
Vは除去修復の第 1 段階に働く醭であり，この研究はヒトとファージの修復機構の共通 性をる示している.

皮膚科に XP らしい患者加来䛦した時，DNA 修復を簡便かつ確実に測定することは容 易ではない，一般に行なわれている方法は，小さい皮膚生検片をとり，堷養して瀻維芽紐 胞を育て，それ决照射した後， ${ }^{3} \mathrm{H}$ ーチミジンを投与して不定期 DNA 合成を測定する (図 2)，この方法はラジオアイソトープ設備を必要とすること，皮膚生険を患者や家族の 同意の下行ならが，1回で必ず結果が出るよらにするため培荃和よび操作炕細心の 注意を要するとともに全過程が最低1か月かかることなど多くの困難がある。しかし，現 
在では日本国内でこ机いつでも行店光る研究室が数か所あるし，生検片を郵便で送って も100\% 成功しているので，XP 診断の決め手として日常的手法となっている.

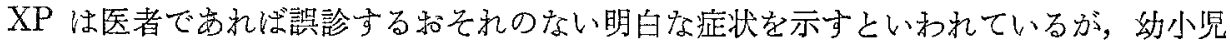
では他の光線過敏症との区別が容易ではないまた啳に述べるように比較的軽症の型るあ る。皮膚がえ発生る予防するには早期以診断を確定せ补ばならず，一見明白な場合です， 生検して修復テストを行らことが望さしい。

\section{3. 色素性乾皮症の遺伝的相補性}

XP の研究が世界で最も進んでいるのはオランダである.D. Bootsma を中心とする研 究グループは体細胞遺伝学の分野で名高いが，その技術を応用してXPの遺伝的相補性を

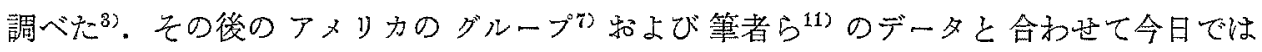

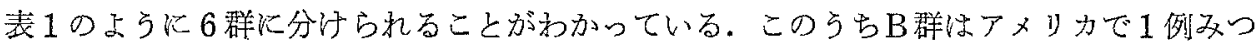
かっているだ付で, Cockayne 症候群を併発していて特殊な例と考克られる。 E群恃，才 ランダに1家族（2例）と日本に1例あるだけで珍しい. Variantは修復合成では正常と 区別できないが，他の方法によってやはりDNA 修復に欠損が認められるもので，除去修

表 1. XP 繯胞の遺伝的相褤性群

\begin{tabular}{|c|c|c|c|}
\hline 相補性群 & $\begin{array}{c}\text { 不定期 DNA 合成 } \\
\text { (正常 } 100 \%)\end{array}$ & 神経症状 & 患者分布 \\
\hline A & $\begin{array}{c}50 \% \text { 以下 } \\
\text { (例外 } 1 \text { 例 } 36 \% \text { ) }\end{array}$ & 大多数あり & 欧米, 日本 \\
\hline B & $3 \sim 7 \%$ & あり & アメリカに 1 例のみ \\
\hline $\mathrm{c}$ & $5 \sim 31 \%$ & なL & 欧米 \\
\hline $\mathrm{D}$ & $25 \sim 55 \%$ & 大多数劳り & 欧米, 日本 \\
\hline E & $40 \sim 70 \%$ & なし & オランダ，日本（2家族のみ） \\
\hline (Variant) & $100 \%$ & なL & 欧米, 日本, イスラエル \\
\hline
\end{tabular}

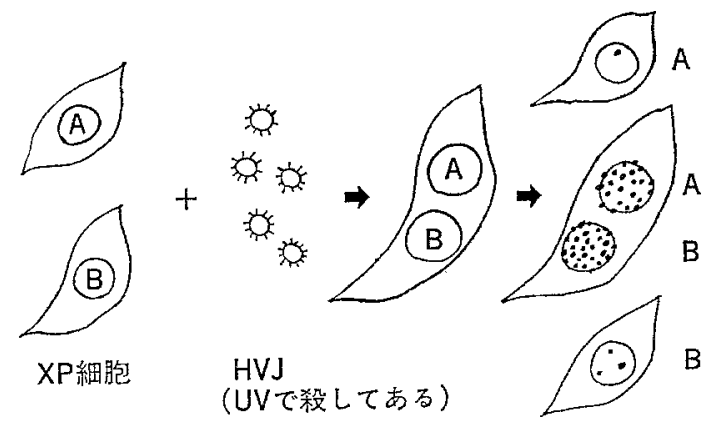

図 3. 細胞融合法を用いた遺层的相補性の判定 単独では修復能が低下している2 采統の細胞がへテロカリオンの 状驡で完全な修復能を示す。 
表 2. 欧米 ${ }^{23}$ と日本 ${ }^{11}$ の XP 相補性群

\begin{tabular}{rrrrrrrr}
\hline \multirow{2}{*}{ 地 域 } & \multicolumn{9}{c}{ 相補性群 } & (Variant) & 合 訫 \\
\cline { 2 - 6 } & $\mathrm{A}$ & $\mathrm{B}$ & $\mathrm{C}$ & $\mathrm{D}$ & $\mathrm{E}$ & & \\
\hline 日 本 & 21 & 0 & 0 & 1 & 1 & 3 & 26 \\
欧 米 & 9 & 1 & 12 & 3 & 2 & 4 & 31 \\
\hline
\end{tabular}

復とは別に働いている複製後修復の欠損と考兄られている。

遺伝的相補性を決める方法は,かつて岡田善雄によって発見された HVJ (Sendai virus) による細胞融合法で，図３に示したように，異なる相補性群に属した細胞る融合させると， 両者が補い合って単独では修復できないものが完全な修復能を示すようになる現象で岁る。 日本の患者の細胞について調べた結果は，表 2 に示すように欧米のデータと著しく暴なっ ていた。ここに含季れていない患者について表 1 の修復合成の割合から推定してみても， この傾向は変らず，C群の患者は日本には全くいないかいても少数で，A群が大半を占め る.日本と欧米のこのような差異は必ずしも驚くに当らないか子しれない. Bloom 症候 群や cystic fibrosis のよらに日本では汪とんどみつからない遺伝病は多いし，逆の場合 もある。また $\mathrm{ABO}$ 血液型でも民族差は大きい。

このような相補性が分子レベルではどのような機構によるものなのか, 現在ほとんど解 明されていない，タンパク質を構成しているサブニニットを示すと考光るにはいくつか無 理な点がある（たとえばT4エンドヌクレアーゼVはモノマー）ので，未知の調整因子が 関与しているか，シストロン内相補性があると考えるにとどめたい。

大腸菌では B-E のよらな中間型の突然変異株林ないのはなぜかとよく尋祇られるが， 扣そらく突然変異体を分離する際に明確に高感受性のものだけを故意に研究者が選ぶから だるうと私以考えている，ヒトの場合には，そのような選抜がないので広いスペクトルを 示すのであるう。

\section{4. 日本の色素性乾皮症のその他の特色}

表 3 K，日本の患者49例のま之めを年踰別飞示した．欧米にくらべ10歳以下の幼小見の 割合が大きいのは，前述のA型が多いことと関連しているものであるう。すなわち DNA


重症になり，皮膚がんす早く発生する．表3では皮膚がんは49例中22例に発生しているが， 幼小児患者はほとえどすべて将来笔生する可能性が高く, 実質的には $90 \%$ 程度の患者に皮 膚がんの発生が予期される。

近親婚は劣性遺伝病の頻度を知る手ががとなるが，同胞例を除き，45組の両親の内訳 はいとこ婚14, いとこ婚以外の近親婚（2 代前まで）8（5ち1例い叔父一めい），近親婚 なし22, 不明 1 組となっている。この割合はかつて川上理一飞よって報告さ礼た約 $40 \%$ \%) よりやや低いが，例数が少ないのでこのデータから遺伝子頻度を求めることは留保したい。 えだ言えることは，欧米にくらべ日本にはXP 患者が多いという印象を受ける。これは幼 
表 3. 日本の色素性教皮症（1976年末）

\begin{tabular}{|c|c|c|c|c|c|c|c|}
\hline \multirow{2}{*}{ 年 龄 } & \multirow{2}{*}{$\begin{array}{c}\text { 患者数 } \\
\text { (佊膚がん) }\end{array}$} & \multicolumn{3}{|c|}{ 神経障害（步行難） } & \multicolumn{3}{|c|}{ 修復合成（対正常\%) } \\
\hline & & $\Phi り$ & なし & 不明 & $\leqq 10$ & $25 \sim 50$ & $70 \leqq$ \\
\hline $0 \sim 9$ & $22(3)$ & $5(4)$ & 0 & 17 & $22(3)$ & 0 & 0 \\
\hline $10 \sim 19$ & $10(7)$ & $7(5)$ & 3 & 0 & $8(6)$ & $1(1)$ & 1 \\
\hline $20 \sim 29$ & $7(5)$ & $2(1)$ & 5 & 0 & $1(1)$ & $2(2)$ & $4(2)$ \\
\hline $30 \sim 39$ & $4(3)$ & 1 & 3 & 0 & 0 & $2(2)$ & $2(1)$ \\
\hline \multirow[t]{2}{*}{$40 \leqq$} & $6(4)$ & 0 & 6 & 0 & 0 & $2(2)$ & $4(2)$ \\
\hline & & & & & \multicolumn{3}{|c|}{ （）内は皮膚がえあり } \\
\hline 合 計 & $49(22)$ & $15(10)$ & 17 & 17 & $31(10)$ & $7(7)$ & $11(5)$ \\
\hline
\end{tabular}

小児期に発見される例が多いためかもしれない。

知能低下，難聴，歩行困難などの神経症状は一般に A，D群に多く例発するとされてい るが，日本のA群は全員（5歳以下の判定困難な例は「不明」としてある）併発している. D群の1例は正常ですった，遗伝学的になぜ神経症状を伴うかは不明である。

\section{5. その他の遗伝学的問題点}

上述のように XP の遺伝的特性の諸機構は DNA 修德については分子レベルまで解明 が進えでいるものの, 相補性など今後解決に努力が必要な点が多い.エジプトの患者で46 例中37例が血液型ぶ $\mathrm{O}$ 型であったこと防か XP と $\mathrm{ABO}$ の連関が指摘され，XP遗伝

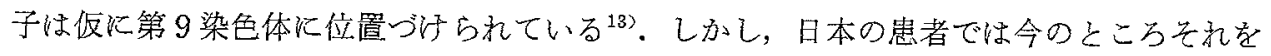
支持も否定もできないデータしかない，同胞例 3 組 7 例がすべてB型とAB型であるため， B型との連関当考觉らるが，データ不足である。

\section{6. なぜ色素性乾皮症は高発がん性か}

この点が XP 研究に新いて学問的に最も與昧深い、仮説は出せるが，実証は容易ではな い、それが実証できる時は，がんがなぜ発生するか解明される時かもしれない。ここでは 筆者らが研究遂行上の一つの作業仮説としている考方方を示音炕とどあたい，この考方方 は近藤宗平（大阪大学医学部）の理諭的考察乱よび大晹菌での実験研究5,6) に急うこころ 线大きい。

XP は，除去修復に欠損を有する。ところが DNA 修復は除去修復以外炕あり，除去 修復が不足しているため, 正常な人よりもとれらの修復（総称して複製後修復しよぶ）が より高率に働く・ところが複製䈦修復ねしばしば修復誤り(エラー）を伴うらしい。すな わち，修復すれ柿する汪どDNA 正しくない配列（二突然変異）を有するようになる。

「がん」もとのような DNA の変化によって起るならば，XP架高発がん性であるこえが 理解できよう。このような考光方は大晹菌で確立され，誤りの多い(error-prone) 修復が 突然変異の原因であるという理論は多くの実験事実によって支持されている.

ヒトにもこの理論を適用するには，細胞レベルでのXP XUV 誘発突然变異や発がえ 
が正常人の細胞より高いことを証明せねばならない。すでに突然変異誘発についてはにぼ 正しいことが証明されているが8)，試験管内発がんについては技術的困難から研究の進展 が遅れている。

この考光方にはいくつかの難点もある。たと完ば複製後修復の低い variant にも発がん がみられるのはなぜか，筆者らは variant も除去修復が低下していることを示すデータを もっているが，複製後修復とのバランス法よくわかっていない。

$\mathrm{XP}$ 以外にも Fanconi 症候群, Ataxia telangiectasia, Bloom 症候群など高発がん性 遺伝病で，から DNA 修復欠損を伴う病気がいくつか知られて蛒り，XP 以似た方法で の研究が 進みつつある ${ }^{10}$. 発がん機構解明の手がかりを求める一つの道としてこのよう なDNA 修復欠損症の研究を，筆者は多くの仲間とともに続けて行きたい。

\section{7. 謝 辞}

XP の研究は基礎・臨床になたがり，しかも技術的に多くの分野の研究者が総合的に取り組えで初 めて可能なるのであったそのような体制づくりにバックアップして下さった近藤宗平教授を初めと する大阪大学医学部放射線基礎医学教室の皆樣に感謝したい，直接の指導, 協力をいただいた岡田善 雄, 三木吉治, 秋葉 弘, 藤原美定, 佐々木正夫, 古山順一, 小塚雄民, 田中刍代次（順不同）の各 氏に感謝するとともに，多くの医師，患者，患者の家族の協力なしにはXP 研究汇着手することすら できなかったことを述べ深謝したい。

\section{文献}

1) Cleaver, J.E. 1968. Defective repair replication of DNA in xeroderma pigmentosum. Nature 218: 652-656.

2) Cleaver, J.E. and Bootsma, D. 1975. Xeroderma pigmentosum. Biochemical and genetic characteristics. Ann. Rev. Genet., 9: 18-38.

3) de Weerd-Kastelein, E.A., Keijzer, W., and Bootsma, D. 1972. Genetic heterogeneity of xeroderma pigmentosum demonstrated by somatic cell hybridization. Nature New Biol., 238: 80-83.

4) El-Hefnawi, H. and Smith, S.M. 1965. Xeroderma pigmentosum. A brief report on its genetic linkage with ABO blood groups in the United Arab Republic. Brit. J. Dermatol., $77: 35-41$.

5) Kondo, S., Ichikawa, H., Iwo, K., and Kato, T. 1970. Base change mutagenesis and prophage induction in strains of Escherichia coli with different DNA repair capacities. Genetics, 66 : 187-217.

6) Kondo, S. 1976. Misrepair model for mutagenesis and carcinogenesis. Proc. 6th Intern. Symp. Princess Takamatsu Cancer Res. Fund, "Fundamentals in Cancer Prevention" (P.N. Magee, et al., eds.) Univ. Tokyo Press, 417-429.

7) Kraemer, K.H., de Weerd-Kastelein, E.A., Robbins, J.H., Keijzer, W., Barrett, S.F., Petinga, R.A., and Bootsma, D. 1975. Five complementation groups in xeroderma pigmentosum. Mutation Res., 33: 327-340.

8) Maher, V.M., Curren, R.D., Ouellette, L.M., and McCormick, J.J. 1976. Effect of DNA repair on the frequency of mutation induced in human cells by ultraviolet irradiation and by chemical carcinogens. Proc. 6th Intern. Symp. Princess Takamatsu Cancer Research Fund, "Fundamentals in Cancer Prevention," (P.N. Magee et al., eds.) Univ. Tokyo Press, 363-382.

9) Neel, J.V., Kodani, M., Brewer, R., and Anderson, R.C. 1949. The incidence of consanguineous matings in Japan with remarks on the estimation of comparative gene 
frequencies and the expected rate of appearance of induced recessive mutations. Am. J. Human Genet. 1: 156-178.

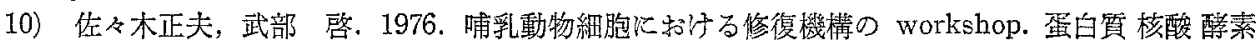
$20: 838-839$.

11) Takebe, H., Miki, Y., Kozuka, T., Furuyama, J., Tanaka, K., Sasaki, M.S., Fujiwara, Y., and Akiba, H. 1977. DNA repair characteristics and skin cancers of xeroderma pigmentosum patients in Japan. Cancer Res. $37:$ 490-495.

12) Tanaka, K., Sekiguchi, M., and Okada, Y. 1975. Restoration of ultraviolet-induced unscheduled DNA synthesis of xeroderma pigmentosum cells by the concomitant treatment with bacteriophage $T_{\&}$ endonuclease $V$ and HVJ (Sendai Virus). Proc. Natl. Acad. Sci. US. 72: 4071-4075.

13) Westerveld, A., Jongsma, A.P.M., Khan, P.M., van Someren, H., and Bootsma, D. 1976. Assignment of the $\mathrm{AK}_{1}$ : NP: $\mathrm{ABO}$ linkage group to human chromosome 9. Proc. Natl. Acad. Sci. US. $73:$ 895-899. 